\title{
Diversity of insect galls associated with Eucalyptus alba \& E. urophylla in altitudinal zones in Timor Island, Indonesia
}

\author{
LINDUNG TRI PUSPASARI ${ }^{1, \bullet}$, DAMAYANTI BUCHORI ${ }^{2}$, ROSICHON UBAIDILLAH ${ }^{3}$, \\ HERMANU TRIWIDODO ${ }^{2}$, PURNAMA HIDAYAT ${ }^{2, \bullet \bullet}$ \\ ${ }^{1}$ Program of Entomology, Graduate School, Faculty of Agriculture, Institut Pertanian Bogor. Jl. Meranti, Kampus IPB Dramaga, Bogor 16680, West \\ Java, Indonesia. Tel.: +62-251-8629354, Fax.: +62-251-8629352, ”email: lindung.tri@unpad.ac.id \\ ${ }^{2}$ Department of Plant Protection, Faculty of Agriculture, Institut Pertanian Bogor. Jl. Meranti, Kampus IPB Dramaga, Bogor 16680, West Java, \\ Indonesia. Tel.: +62-251-8629354, Fax.: +62-251-8629352, ^"email: phidayat@apps.ipb.ac.id \\ ${ }^{3}$ Research Center for Biology, Indonesian Institute of Science. Jl. Raya Jakarta-Bogor Km. 46, Cibinong, Bogor 16911, West Java, Indonesia
}

Manuscript received: 14 October 2020. Revision accepted: 13 June 2021.

\begin{abstract}
Puspasari LT, Buchori D, Ubaidillah R, Triwidodo H, Hidayat P. 2021. Diversity of insect galls associated with Eucalyptus alba \& E. urophylla in altitudinal zones in Timor Island, Indonesia. Biodiversitas 22: 2667-2679. We investigated the galling insects associated with two species of Eucalyptus, namely E. alba Reinw. and E. urophylla S.T. Blake in different altitudinal zones in Timor Island, Indonesia. This is the first report for Indonesia of the diversity patterns and community structures of galling insects in these two species of eucalyptus and the type of galls they produce. Surveys and data collection were carried out between October 2017 and June 2018 at different altitudes of secondary forest in Timor Tengah Selatan district, Timor. We visited five altitudinal zones $( \pm 829 \mathrm{~m}$ asl., \pm $942 \mathrm{~m}$ asl. $\pm 1,621 \mathrm{~m}$ asl., $\pm 1992 \mathrm{~m}$ asl., and $\pm 2457 \mathrm{~m}$ asl.) and selected 25 eucalyptus plants of 3 to $5 \mathrm{~m}$ in height in each altitudinal zone from which to collect insect galls. The galls were observed on leaves, upper leaves (shoots), outer leaves, symptomatic twigs and stems. The galls were taken to the laboratory for rearing of the insects they contained. A total number of 12 gall types were found in $E$. alba and 15 in E. urophylla from which 28 insect morphospecies were identified belonging to 16 families and five orders. The order Hymenoptera was represented by ten families: Bethylidae, Torymidae, Eulophidae, Eupelmidae Eurytomidae, Pteromalidae, Encyrtidae, Mymaridae, Braconidae and Scelinonidae while the order Diptera was represented by three families: Fergusoninidae, Cecidomyiidae and Chaoboridae. Galling species diversity ranged from 1.71 to 2.38 on the Shannon-Wiener index and 0.75 to 0.87 on the Simpson index and showed that the galling-insect communities were species-rich and composed of galling formers and very few inquilines. In the study, communities are categorized and structured according to different types of galling insects, including those that induce galling, those that are parasitoid, and those that are inquiline. Within the category of gall-forming insects in the two species of eucalyptus, Eulophidae is found to be the dominant family. Our field data makes an important contribution to basic knowledge of insect galling patterns in eucalyptus forests and constitutes baseline data for the implementation of pest control.
\end{abstract}

Keywords: Eucalyptus, gall, Lesser Sunda, Myrtaceae

\section{INTRODUCTION}

Gall-forming insects are among the most interesting living arthropods, not only because of their specialist mode of life but also because there are so many species within the group. As a result, research into gall-inducing insects has received much attention in recent years and studies into species diversity patterns and composition on particular plants have been published for a number of regions. From a species richness point of view, there are estimated to be around 132,930 species of galling insects worldwide (with individual estimates ranging from 21,000 to 211,000 species) (Espírito-Santo and Fernandes 2007). Despite the region's rich biodiversity, there is limited information available on the galling insects to be found in Indonesia.

Previous research into galling insects in Indonesia was pioneered by Van Leeuwen-Reijnvaan and Van Leeuwen (1926), who reported a number of galling insects on various plants. They also described a range of causes of galls, such as nematodes, insects and mites, of which most were caused by insects from the Cecidomyiidae family that attack the leaves of plants (Van Leeuwen-Reijnvaan and Van Leeuwen 1926). Some galling insects are important as pests in forest ecosystems and agroecosystems and recently, knowledge about galling insects in agroecosystems has been developing. In Indonesia, the pest Asphondylia capsicum has been reported to attack Capsicum annuum and $C$. frutescens chili plants in Cisarua, Bogor (West Java), Gianyar, (Bali), and Dropingi (Sumatra) (Uechi et al. 2016). In addition, some years ago Orseolia oryzae WoodMason (Diptera: Cecidomyiidae) was reported to be a major pest in rice (Roksosoesilo 1985). In the last ten years, galling insects in forest ecosystems have been studied only in industrial forests, with Ophelimus eucalypti (Hymenoptera: Eulophidae) having been reported to attack estimated to be around 132,930 species of galling insects worldwide (with individual estimates ranging from 21,000 to 211,000 species) (Espírito-Santo and Fernandes 2007). Despite the region's rich biodiversity, there is limited information available on the galling insects to be found in Indonesia. Industrial eucalyptus plantations in North Sumatra (Ubaidillah 2011). Research into galling insects in 
a wider range of plants in Indonesia so far comprises only an inventory and descriptions of types of gall (Rachman et al. 2012, 2014) and there is almost no research as yet into insect galls on eucalyptus in natural ecosystems, in particular in eastern Indonesia.

East Lesser Sunda is particular type of dry temperate forest in eastern Indonesia that has several examples of endemic flora and fauna and may therefore support unique plant-animal interactions, including those involving gall formers. However, gall-forming interactions, specifically the species diversity of galling insects associated with Eucalyptus spp. in natural forests in the area, have yet to be investigated. The only study of galling insects on eucalyptus was recently carried out by Safitri (2019) and is focused on industrial eucalyptus plantations. Indonesian eucalyptus is known to grow naturally on several islands including Timor, Papua, and Sulawesi Islands (CABI 2005). In this study, eucalyptus in Timor is recorded mainly at the Forest Nature Reserve of Mount Mutis in the district of Timor Tengah Selatan, located in the altitude range of $\pm 800 \mathrm{~m}$ asl. to $\pm 2400 \mathrm{~m}$ asl.. The objective of this study was to ascertain the diversity of species and investigate the composition patterns of gall-forming insects on two species of eucalyptus, namely $E$. alba and $E$. urophyla, in the Forest Nature Reserve of Mount Mutis (NRMM) and in the buffer zone of the dry forest reserve in Timor Tengah Selatan District, Timor Island. This is the first study of gall-inducing insects in tropical dry forests of Indonesia. Its contribution in terms of galling-insect assemblage and the estimation of local species richness in eucalyptus is essential to general ecological perspectives, especially for the development of understanding of species' richness patterns and their implications.

\section{MATERIALS AND METHODS}

\section{Study area}

The study was conducted in the Nature Reserve of Mount Mutis (NRMM), latitude $9^{\circ} 38^{\prime} 25^{\prime \prime} \mathrm{S}$ longitude $124^{\circ} 13^{`} 14^{\prime} \mathrm{E}$, located about $40 \mathrm{~km}$ north of Timor Tengah Selatan subdistrict, East Lesser Sunda, Indonesia. Sampling was carried out over three months between June 2017 and May 2018. The sampling of galling insects was conducted according to the presence of eucalyptus trees found in NRMM and in the buffer zone. The research areas represent dry forest consisting of homogeneous vegetation with a small number of species trees, of which E. urophylla is the most dominant (Simbolon and Sukendar 1987), and rehabilitation forest in the buffer zone of NRMM. NRMM is situated in the Mount Mutis area in the altitude range 1500-2400 $\mathrm{m}$ asl.. The five sites selected as sampling locations have been widely used in previous botanical studies (Simbolon and Sukendar 1987; Pujiono et al. 2019), two sites being in the NRMM buffer zone and three others in NRMM itself: Site 1 with altitude of $829 \mathrm{~m}$ asl., at latitude $9^{\circ} 50^{\prime} 59^{\prime \prime S}$ longitude $124^{\circ} 16^{\prime} 20^{\prime \prime} \mathrm{E}$ and Site 2, at altitude $942 \mathrm{~m}$ asl., latitude 9'50'16"S longitude $124^{\circ} 15^{\prime} 36^{\prime \prime} \mathrm{E}$ are both in the buffer zone, while Site 3, altitude $\pm 1621 \mathrm{~m}$ asl., latitude: $9^{\circ} 38^{\prime} 25^{\prime}{ }^{\prime} \mathrm{S}$ longitude $124013{ }^{`} 14^{\prime \prime} \mathrm{E}$, Site 4 at $1992 \mathrm{~m}$ asl., latitude 9०34`39' $\mathrm{S}$ longitude $124^{\circ} 13 ` 59^{\prime} \mathrm{E}$ and Site 5, altitude $\pm 2457 \mathrm{~m}$ asl., latitude $9^{\circ} 33^{\prime} 37^{\prime} \mathrm{S}$ longitude $124^{\circ} 133^{\prime} 39^{\prime} \mathrm{E}$, are in NRMM itself (Figure 1).

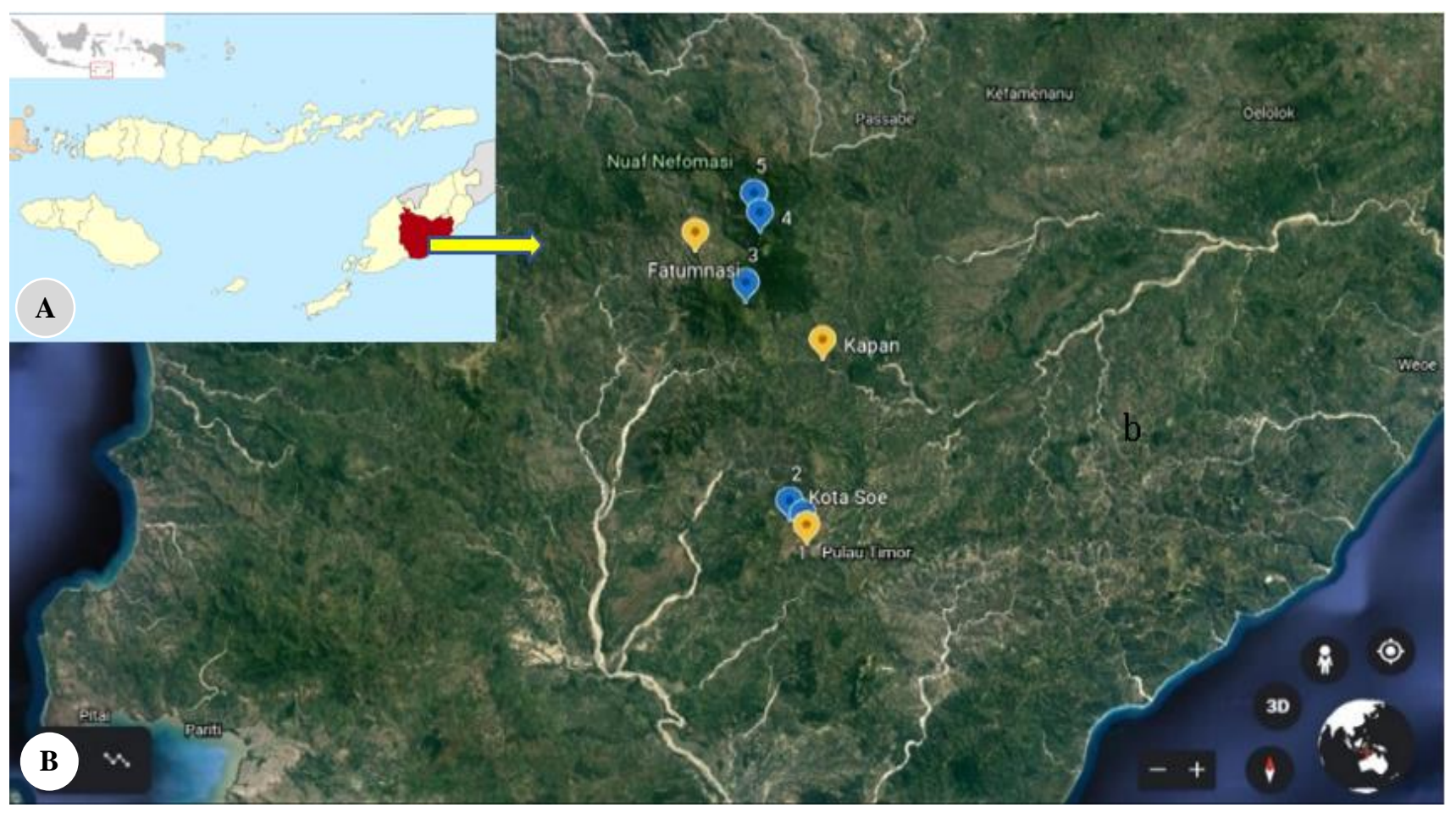

Figure 1. Map of East Nusa Tenggara Province, Indonesia: A. Location of Timor Tengah Selatan District; B. Satellite view of Mount Mutis Nature Reserve (NRMM) at an altitude of 1500-2400 m asl. and buffer zone (800-1000 m asl.) displaying the five sampling sites 
Galling-insect sampling and identification

At each sample site, 25 plants for both E. alba and $E$. urophylla were randomly selected. The sampling of galling insects and plant organs, including branches, stems, leaves, flowers and fruits at heights of between 3 and $5 \mathrm{~m}$ was observed by two persons Each insect gall found was collected and put into a separate plastic bag and transported to the laboratory for photographic registration of gall morphotype, rearing insect and gall insect identification. Samples of galls from branches, stems, leaves, flowers and fruits were identified to morphospecies. The gall morphotype was identified through external morphology characteristics including shape, color, and trichomes (Isaias et al. 2013). The relationship between galling insects and the host of each gall morphotype was considered in identifying the morphospecies of galling insects. We identified each galling insect emerging from each morphotype to species level whenever possible and recorded them for estimating the number of galling-insect morphospecies and number of morphotypes. The use of morphospecies to represent the richness of galling species is widely accepted in several studies (e.g. Santos et al. 2011a; Silva et al. 2011). All insect galls collected were deposited at IPB and Museum Zoologicum Bogoriense, Indonesian Institute of Sciences as voucher specimens.

\section{Data analysis}

The diversity and relative abundance of species are analyzed according to Shannon and Simpson's diversity index. Statistically, when all species are represented in a sample and all samples are taken at random, diversity can be reflected via the Shannon diversity index. Meanwhile, common or dominant species will be given more weight in the Simpson diversity index and the existence of species with only few representatives will not affect diversity. Our data will be measured using Shannon's index $\left(\mathrm{H}^{\prime}\right)$ as shown in Equation 1:

$$
H^{r}=\sum_{i=1}^{s} p i \ln p i
$$

In which $p$ is the proportion $(\mathrm{n} / \mathrm{N})$ of individuals of one particular species found (n) divided by the total number of individuals found $(\mathrm{N})$. In the natural $\log$ (Equation 2), $\sum$ is the sum of the calculations and $S$ is the total number of insect species found in the community. Meanwhile, Shannon's equitability $\left(E_{H}\right)$ can be measured by dividing $H$ by $H_{\max }$ (here $H_{\max }=1 \mathrm{n} S$ ). Equitability assumes a value between 0 and 1 , with 1 being complete evenness (E).

$$
E=H^{r} / \ln \xi
$$

The vertical distribution of galling insects associated with the two eucalyptus species was analyzed using (one way) ANOVA to understand the number of galling-insect species at each site, as presented in a boxplot format using R Statistic 3.0.2 software. The species richness of galling insects and their distribution in E. urophylla at various elevations were also analyzed using a Venn diagram
(Oliveros 2007). Meanwhile, the Bray Curtis similarity index (Ludwig and Reynolds 1988) was used to analyze the structure and species composition of the galling insects associated with eucalyptus galls in the two species at different altitudes.

\section{RESULTS AND DISCUSSION}

\section{Species diversity of galling insects}

In total, 28 galling-insect morphospecies belonging to five orders and 17 families were identified from a set of 1558 individuals collected in the five different altitudinal localities. This included 28 morphospecies from four genera and eight families associated with E. alba, and 28 morphospecies from five genera, and 17 families associated with E. urophylla, from different altitudinal locations (Table 1).

We also found some interesting characteristics for this group of insects in both E. urophylla and E. alba. Comparisons of host and galling-insect richness along altitudinal gradients showed that E. alba occurs only in the lowlands at Site 1 and that the peak of species richness also appears at this site. E. alba was planted for forest regeneration about 7 to 10 years ago (Soleman Toto, pers.com 2018) and interestingly E. urophylla was not found in Site 1 or in low elevations. E. alba mainly grows between 800 and $1000 \mathrm{~m}$ asl. while E. urophylla grows between 900 and $2500 \mathrm{~m}$ asl.. Comparisons between low and highland habitats also showed that galling insects were most species-rich and abundant in Site 1 which was dominated by $E$. alba. The species richness of galling insects differed significantly between $E$. urophylla and $E$. alba with $\chi^{2}=1.9885, P=0.000$, and $n=25$. The species abundance of galling insects differed significantly between E. urophylla and E. alba with $\chi^{2}=35.555, P=0.000$, and $n=25$.

The species diversity indices showed values ranging from 1.71 to 2.38 (Shannon-Winner index) (Table 2). The lowest diversity was found in E. urophylla at an altitude of $2000 \mathrm{~m}$ asl., with $H$ value of 1.71 .

On the whole, the study results showed that gallinginsect diversity in the two species of eucalyptus does not vary greatly from site to site, however, statistical analysis shows slightly significant difference. The Simpson index value is between 0.75 and 0.87. A low Simpson index value was obtained at Site 4 (E. urophylla; $1992 \mathrm{~m}$ asl.) whereas the highest value was obtained at Site 2 ( $E$. urophylla; $942 \mathrm{~m}$ asl.). A statistical analysis by Tukey (Figure 4) revealed that Site 1 was significantly different from Sites 2, 4 and 5, whereas Site 3 was not significantly different. The index value of galling insects related to the two species of eucalyptus with less than one example of insect was categorized as low (Magurran 2004). Based on the dominance index (D), the values varied from 0.13 to 0.26 in E. urophylla at Sites 2 to 5 and 0.16 in E. alba at Site 1. Our findings suggest that the indices for dominant galling insects in both eucalyptus species have values of under 0.5 and range of index (D) of $0<\mathrm{D} \leq 0.5$. The dominance index values range from 0 to 1 , being equal to 
0.5 when all species have the same abundance and confirming there neither $E$. alba nor E. urophylla dominates. The level of species dominance and abundance would be influenced by the host and physical factors (De Araújo et al. 2013; Barbosa and Fernandes 2014) such as elevation which can directly shape species dominance in eucalyptus galling insects.

The galling insects found in the two species of eucalyptus include gall wasps (Hymenoptera), gall midges (Diptera: Cecidomyidae), psyllids (Hemiptera: Psyllidae), leaf moths (Lepidoptera: Tortricidae) and thrips (Thysanoptera: Phlaeothripidae). Among these species of galling insects, 20 are Hymenoptera, four Diptera, two Hemiptera, one Thysanoptera and one Lepidoptera (Table 6). Hymenoptera gall wasps are the most dominant galling insect in both eucalyptus species, at $64 \%$ in E. urophylla and $50 \%$ in E. alba (Figures 2 and 3). In E. urophylla this is followed by gall midges at $29 \%$ and psyllids at $7 \%$, meanwhile, in E. alba the dominance of gall wasps is followed by gall midges at $25 \%$, Lepidoptera at $13 \%$ and Thysanoptera at $12 \%$ (Figure 3 ).

Relative abundance of galling insects in both eucalyptus types was also calculated, and Table 2 showed the most dominant species in the NRMM. The relative abundance of gall species might be related to the compatibility of host plants and suitable habitat conditions. Here we attempt to discuss each of the two eucalyptus species and their galling insects in each vertical distribution. Species richness and distribution patterns along altitudinal gradients have shown that the peak number of species occurs in E. alba between 800 and $1000 \mathrm{~m}$ asl. in areas covered not only by $E$. alba but also by other vegetation (Chromolaena odorata, and Erechtites valerianifolia).

Table 1. Number of galling-insect species associated with each eucalypt species in Mount Mutis Nature Reserve, Timor Tengah Selatan District, Timor Island, Indonesia

\begin{tabular}{ccccc}
\hline $\begin{array}{c}\text { Sampling site/altitude } \\
\text { (m asl.) }\end{array}$ & Eucalyptus species & $\sum$ morphospecies & $\sum$ families & $\sum$ orders \\
\hline 829 & Eucalyptus alba & 17 & 8 & 4 \\
942 & E. urophylla & 16 & 9 & 3 \\
1621 & E. urophylla & 16 & 10 & 3 \\
1992 & E. urophylla & 12 & 7 & 3 \\
2457 & E. urophylla & 28 & 17 & 3 \\
Total & & & 5 \\
\hline
\end{tabular}

Table 2. Species richness and diversity indices for galling insects on E. alaba and E. urophylla in Mount Mutis Nature Reserve, Timor Tengah Selatan District, Timor Island, Indonesia

\begin{tabular}{cccccc}
\hline Elevation m asl. & S & N & H & E & 1-D (Simpson) \\
\hline $828($ E. alba $)$ & 17 & 359 & 2.147237 & 0.75788 & 0.837377 \\
$942($ E. urophylla $)$ & 16 & 517 & 2.379262 & 0.858138 & 0.868108 \\
$1621($ E. urophylla $)$ & 16 & 701 & 1.789869 & 0.645559 & 0.770593 \\
$1992($ E. urophylla $)$ & 12 & 212 & 1.711849 & 0.688899 & 0.746663 \\
2457 E. urophylla $)$ & 12 & 129 & 2.149063 & 0.864847 & 0.864491 \\
\hline
\end{tabular}

Note: S: Species number, N: Individual number, H: Shannon-Wiener Index, E: Eveness Index

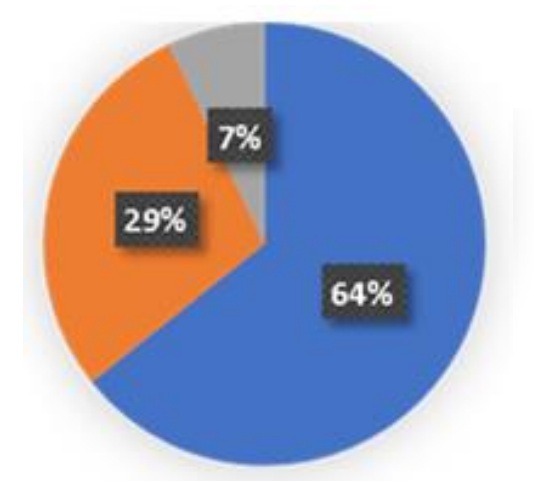

Figure 2. Proportion of galling insects on Eucalyptus urophylla

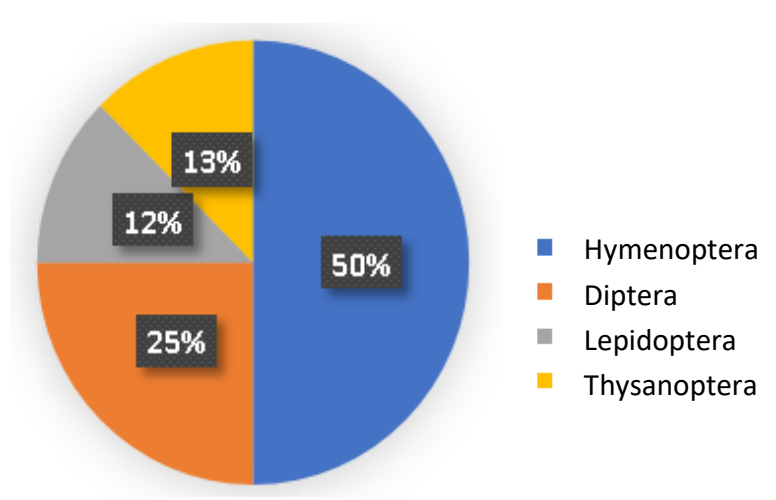

Figure 3. Proportion of galling insects on Eucalyptus alba 
Our hypotheses have been proposed to explain variation in species richness and diversity of galling species in two species of eucalyptus in NRMM. Richness of host-plant species can be a potential factor (e.g. De Araújo 2011 ), a negative relationship between altitude and gall species richness might be dependent on differential proportion of xeric versus mesic habitats, nutrient availability, variable top-down control of gall populations, and/or plant resistance traits among others (Quintero et al. 2014). Our research in NRMM shows greatest species richness revealed in the lowland of Site 1 (in $E$. alba). Based on this hypothesis, the forest regenerated with eucalyptus has higher richness than highland areas. Our results are incongruent with this hypothesis because the regenerated forest was richer in species of galling insects than other areas of wild eucalyptus forest; this finding requires further study.
Although the purpose of this study was not to compare the richness of galling insects among the sample areas, it is important to emphasize that the galling insects in eucalyptus forest showed approximately half (27 morphotypes) of all the species found in this survey. This pattern could be produced by the atypical vegetation of this forest, revealed as having a pattern of plant species different from those of the NRMM lowland and highland, with part of its flora representing the geographical distribution covering highland vegetation formations.

The species richness of galling insects associated with the two species of eucalyptus is closely related to insect behaviors themselves. Analysis of the number of individuals and species as well as the distribution of insects associated with eucalyptus galls is presented in the form of boxplot diagrams (Figures 4 and 5).

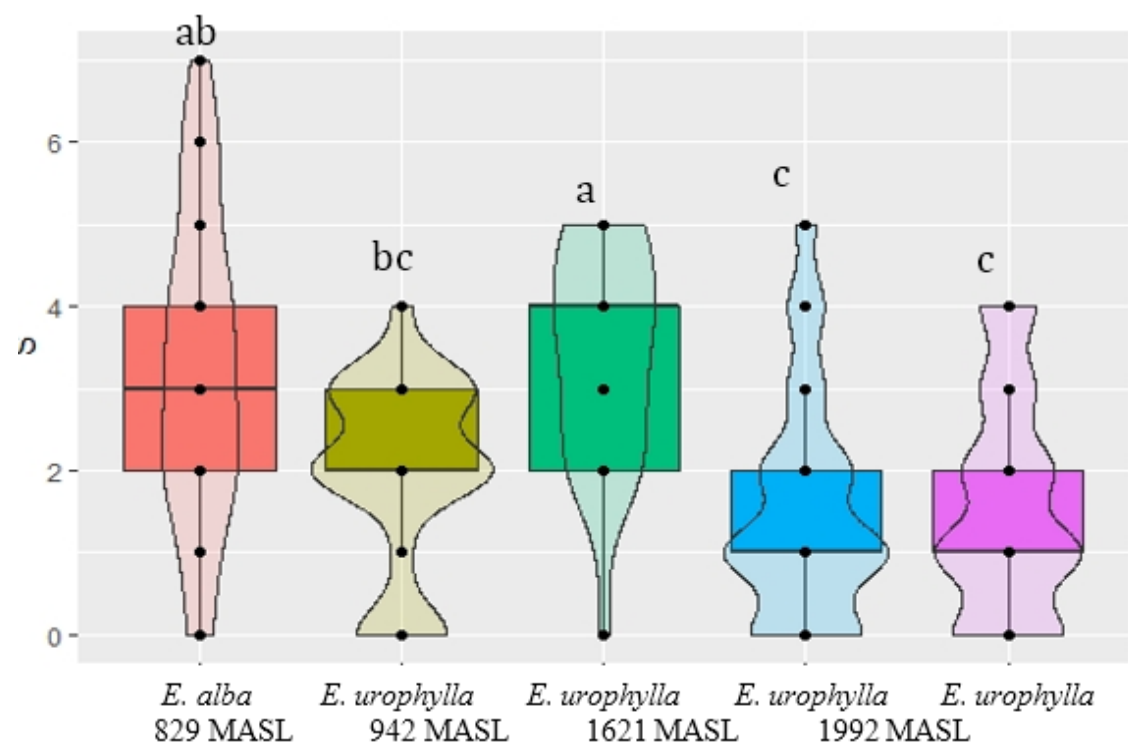

Figure 4. Species richness of galling insects in both Eucalyptus alba and E. urophylla in Mount Mutis Nature Reserve, Indonesia

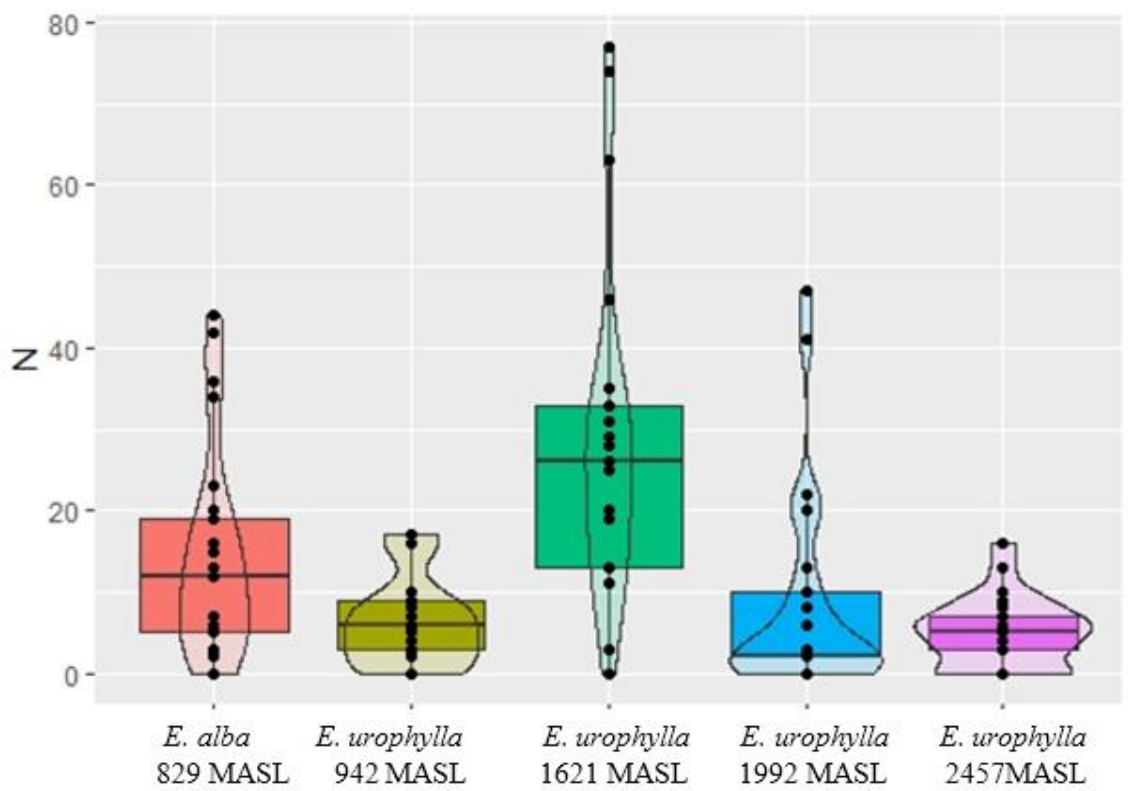

Figure 5. Abundance of species of galling insect in both Eucalyptus alba and E. urophylla in Mount Mutis Nature Reserve, Indonesia 
Species richness at several altitudes based on ANOVA analysis followed by Tukey's range test) showed that $(\mathrm{P}=0.0003<0.05)$ were significantly different in the two eucalyptus plant species at different altitudes. While the abundance of individuals at several altitudes did not show a significant difference based on the results of Anova $(\mathrm{P}=0.0843>0.05)$. Variations in the number of individuals and insect species associated with eucalyptus galls were higher in E. urophylla at an altitude of $1621 \mathrm{~m}$ asl.. The results of this analysis confirm that differences in eucalyptus species and altitude do affect the number of individuals and the number of species of galling insects associated with them. The eucalyptus may be a particularly important host for species of galling insects such as gall wasps (Hymenoptera), gall midges (Diptera Cecidomyiidae) and psyllids (Hemiptera: Psylidae) which are generally weak fliers.

Based on the analysis of the Venn diagram (Figure 6) it can be seen that species richness at several altitudes in $E$. urophylla is almost the same. However, there are some species that are only found at certain elevations. Three species are only found at an altitude of $942 \mathrm{~m}$ asl., namely Bethylidae sp.1, Eulophidae sp.2, and Eupelmidae sp.1. Likewise, three species were found at an altitude of $1621 \mathrm{~m}$ asl., namely Scelionidae sp.1, Chaoboridae sp.1, and Psyllidae sp.2, and one species was only found at an altitude of 1992 m asl., namely Braconidae sp. 2.

The structure and species composition of the galling insects associated with the two species of eucalyptus at different vertical elevations were analyzed using the Bray Curtis similarity index. Similarity of species at various altitudes shows differences ranging from 0.19 to 0.49 . The closest similarity of insect species was seen in E. urophylla at an altitude of $2457 \mathrm{~m}$ asl. and at an altitude of $1992 \mathrm{~m}$ asl. (Table 3).

This shows that the forest habitat of E. urophylla at an altitude of $2457 \mathrm{~m}$ asl. has the same host source and microclimate conditions as 1992. This is in line with the opinion of several previous researchers (Koneri 2010; Cleland 2011) who state that the structure of vegetation, microclimate conditions and human interference can influence the structure of insect communities.

\section{Types of gall forms in $E$. urophylla and $E$. alba}

In this study, various gall morphologies were found, from simple galls, such as folded, rolled and swollen leaves, to complex gall types, such as increases in the size and volume of cells, tissues or certain organs in different parts of the plant. The most influencing factor for the diversity of gall morphology is the insects that interact with the gall, either directly or indirectly. According to EspíritoSanto and Fernandes (2007), the diversity of insects related to galls in the tropics is higher than in subtropical and temperate regions such as North America. Fernandes and Price (1992) state that there is a positive relationship between insects associated with galls and plant wealth in tropical regions such as Indonesia.

Our study shows there are 27 morphologically distinct types of insect galls in both species of eucalyptus. For $E$. alba there are those in Figure 7.A, B, C, D, G, H, I, K, L (leaves), buds (Figure 7.J), twigs (Figure 7.E), and trunks (Figure 7.F) while in E. urophylla there are those in leaves (Figure 8.M, N, O, P, Q, U, V, W, X, Y, Z, AA), buds (Figure 8.R), twigs (Figure 8.S), and axillae (Figure 8.T).

Table 3. Bray Curtis similarity index for galling insects associated with Eucalyptus alba and E. urophylla

\begin{tabular}{cccccc}
\hline Elevation (m asl.) & $\mathbf{8 2 9}$ & $\mathbf{9 4 2}$ & $\mathbf{1 6 2 1}$ & $\mathbf{1 9 9 2}$ & $\mathbf{2 4 5 7}$ \\
\hline 829 & 1 & & & & \\
942 & 0.41 & 1 & & & \\
1621 & 0.27 & 0.27 & 1 & & \\
1992 & 0.23 & 0.44 & 0.26 & 1 & \\
2457 & 0.25 & 0.37 & 0.19 & 0.49 & 1 \\
\hline
\end{tabular}

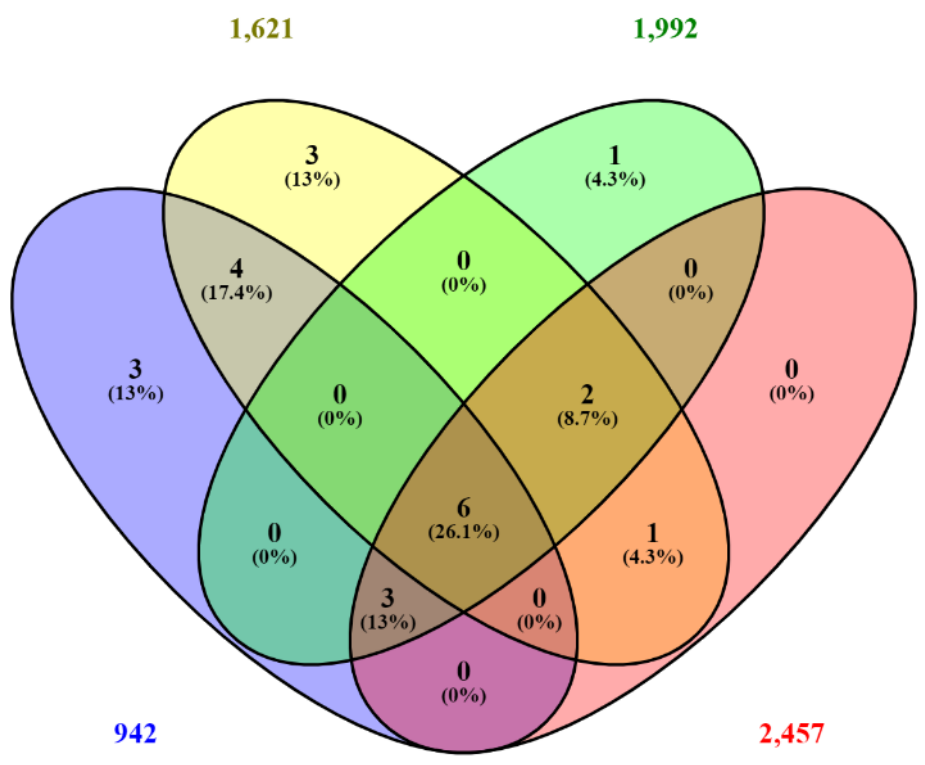

Figure 6. Species richness and distribution of insect galls in Eucalyptus urophylla at various elevations using Venn diagram analysis 
Our results showed that leaves have a higher percentage of galls than other plant organs, at $75 \%$ of those found in $E$. alba and $80 \%$ in E. urophylla (Figure 9). The galls found in axillae are categorized as galls on twigs. The results of this study agree with previous studies by Rachman et al. (2014). Rachman et al. (2012) confirmed that $98 \%$ of galls were found in leaves and a similar finding was reported by, Toma and Mendonça-Junior (2013) who stated that the preference for galls to be formed in leaves was a general pattern that occurred worldwide. Miller and Raman (2019) suggest that leaves are the most susceptible organs for gall development. Leaves are usually the most available plant organs and therefore the most susceptible to gall induction. These organs are also more abundant and easily observed, in contrast to the other plant organs; they are more plastic (Formiga et al. 2013), and have a larger potential to respond to galling stimuli.

The galls found in E. alba and E. urophylla vary in terms of their shape and the parts of the plants on which they are located. The differences in the types and forms of gall in E. alba and E. urophylla are thought to be due to the different characteristics of the two types of eucalyptus. The galls formed in the two eucalyptus species were grouped into 13 gall types based on their similarity in shape and their inducing insect (Table 4). In E. alba there are eight types of gall while in $E$. urophylla there are ten types. The gall species GT 7, GT 10 and GT 12 were only found in $E$. alba while GT 8, GT 9, GT11 and GT 13 were only found in E. urophylla.

Our results indicated that the types of galls found at various elevations in the two eucalyptus species in NRMM differ. In $E$. alba there were eight types of gall while in $E$. urophylla there are 11, at different elevations. Gall types GT 7, GT 10 and GT 12 were only found in E. alba while gall types GT 8, 9, 11 and 13 were only found in $E$. urophylla at an altitude of $1500 \mathrm{~m}$ asl.. The results shown in Table 5 and Table 6 have strengthened our opinion that gall species diversity decreases at higher elevations. There are different types of gall found in E. alba and E. urophylla at different heights, namely GT1, 2, and 3.

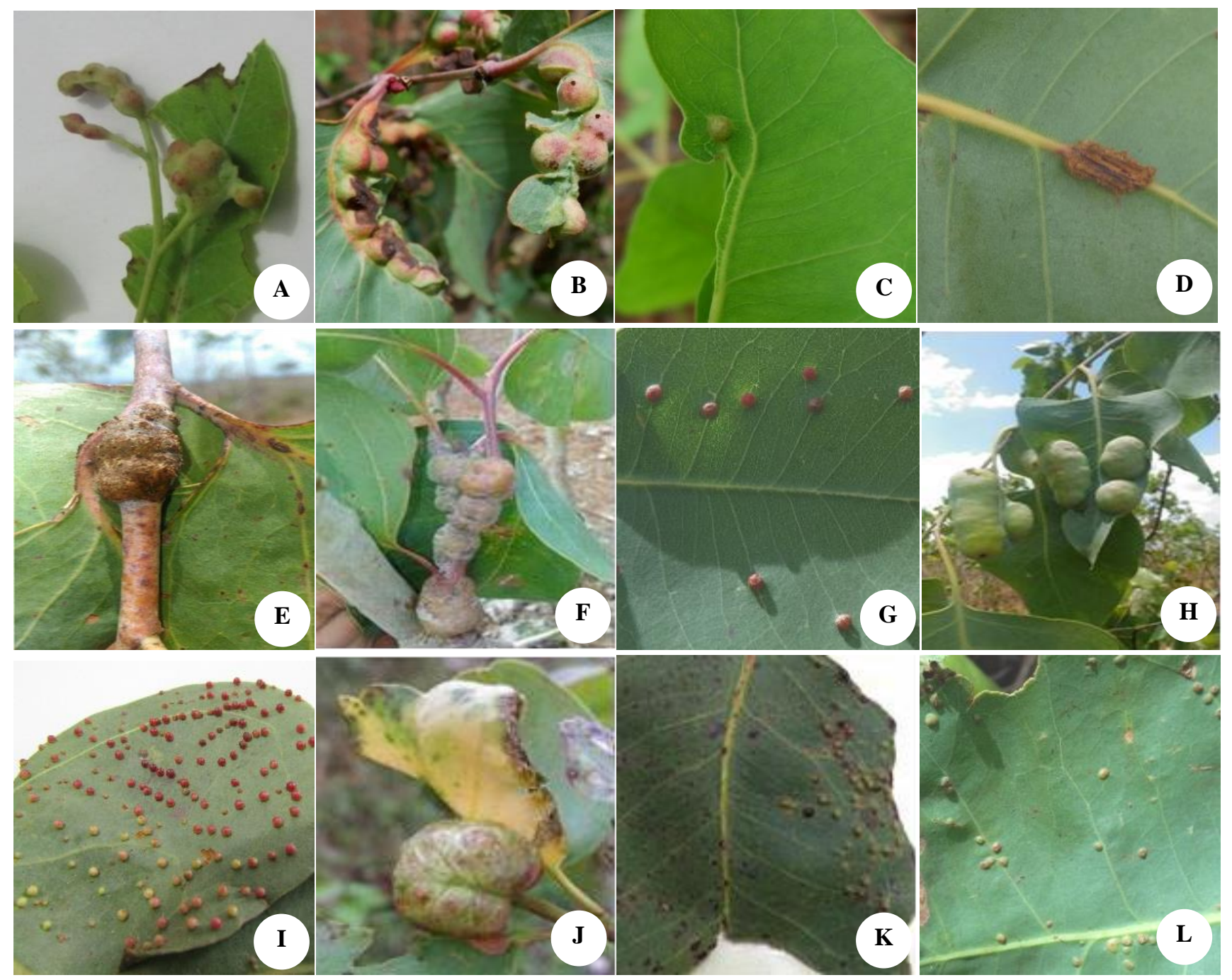

Figure 7. Types of gall forms in Eucalyptus alba: leaves (A, B, C, D, G, H, I, K, L); bud (J); twig (E), and trunk (F) 

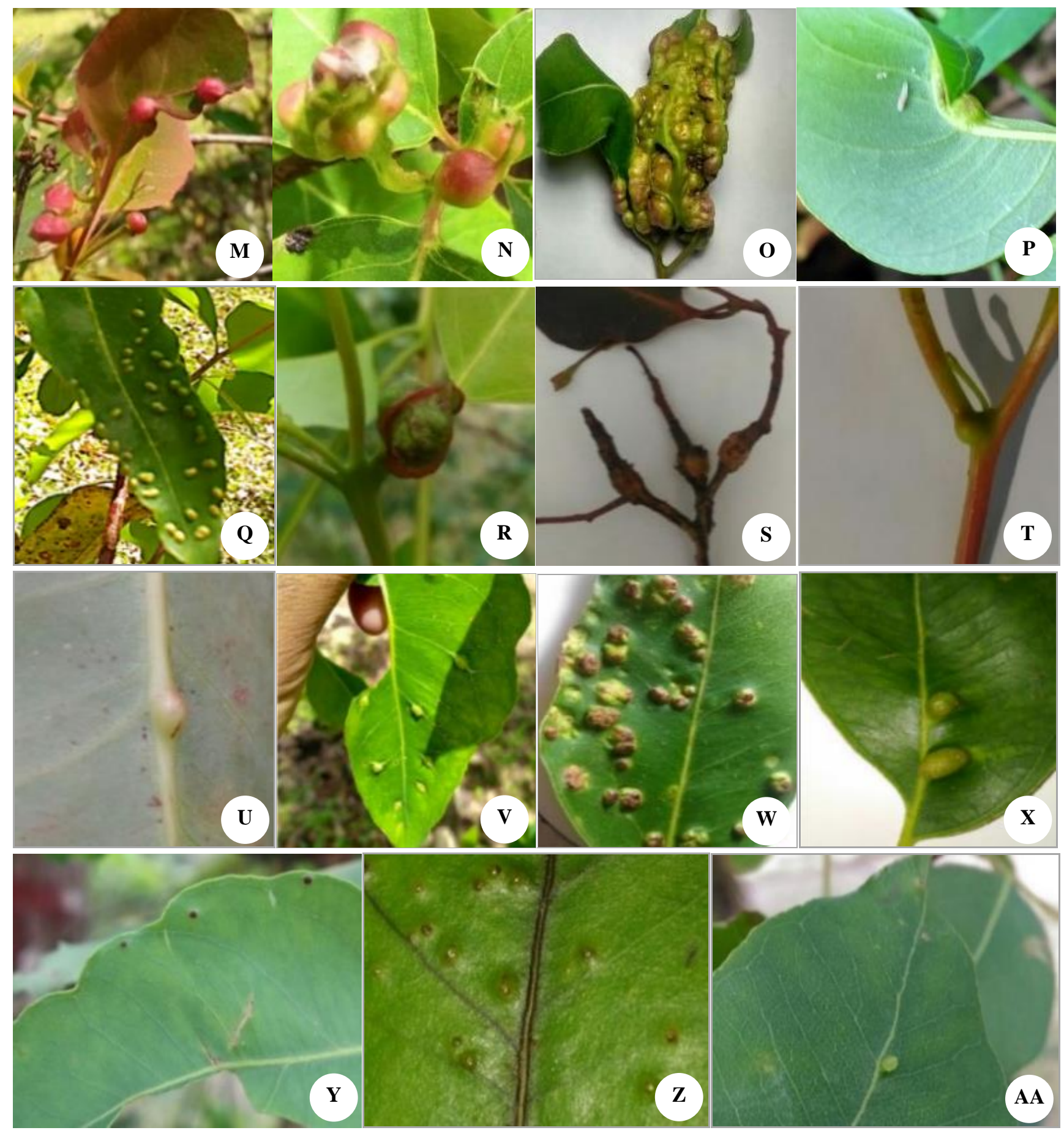

Figure 8. Types of gall forms in Eucalyptus urophylla: leaves (M, N, O, P, Q, U, V, W, X, Y, Z, AA); bud (R); twig (S); and axilla (T)

Gall-forming organisms can achieve greater success than herbivores, living freely in more stressful environments. Modifications to galls in terms of size, shape or other defense systems will increase the protection of the gall-inducing insect from predators and parasitoids. The gall-causing insects must be able to manipulate the host plant as needed to protect against natural enemies and thus increase their survival. The more various the gall shapes and sizes, the more insects interact with them. Classical studies as those of Fernandes and Price (1992) suggest that gall abundance usually decreases with altitude due to the sensitivity of gall-inducing insects to changes in humidity and temperature associated to increased altitude. More recent studies such as Carneiro et al. (2014) have suggested, however, that altitude might influence gall abundance only in xeric habitats, as the morphological structure created by the gall actually protects the growing larvae against climatic harsh and natural enemies. 


\section{Discussion}

There has been little research into galling insects on eucalyptus in Indonesia, either in natural forests or in the eucalyptus tree industry, and only a few publications have just appeared in the last two years (Safitri et al. 2019; Syawalludin et al. 2019). This study represents the first contribution to the understanding of species richness of galling insects and the types of galls they produce in mixed natural forests in which eucalyptus is the dominant tree. As height increases towards the top of Mount Mutis, the domination of E. urophylla decreases while other plants such as $P$. imbricatus and Casuarina junghuniana become increasingly prominent, but $E$. urophylla still remains the main tree species to the summit (Simbolon and Sukendar 1987). The presence of insects associated with gall on $E$. urophylla at an altitude of $1621 \mathrm{~m}$ asl. was higher than other lands because at an altitude of $1621 \mathrm{~m}$ asl. there was more canopy than at an altitude of $1992 \mathrm{~m}$ asl. which was dominated by grasslands. The more diverse the canopy in an area, the more host insects or natural enemies will interact (Horstmann et al. 2005). This indicates that there are differences in eucalyptus species and the height of the number of insect morphospecies associated with eucalyptus clumps. Differences in insect diversity between elevations and between different eucalyptus species are possible if there are differences in landscape structure.

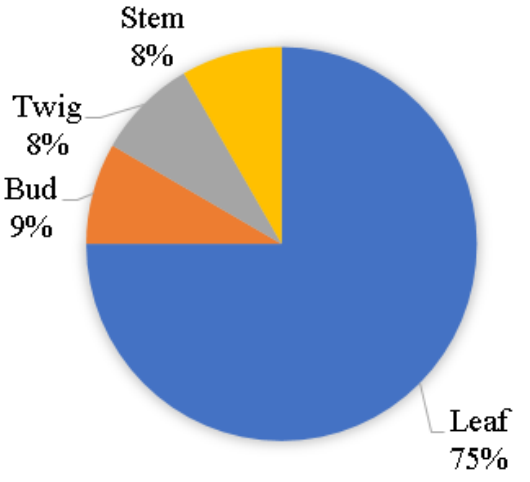

A

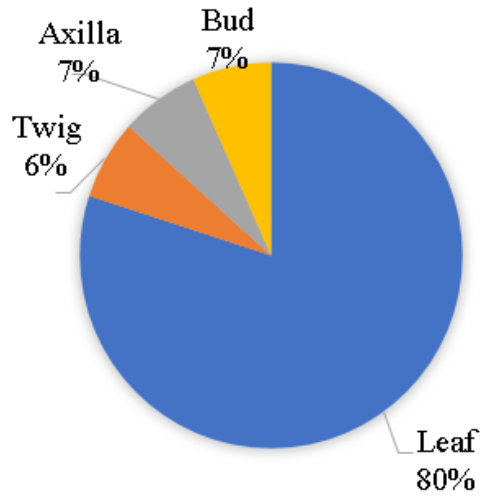

B

Figure 9. Proportion of plant organs with galls: A. Eucalyptus alba, B. E. urophylla

Table 4. The types of gall and gall forms found in Eucalyptus alba and E. urophylla

\begin{tabular}{|c|c|c|c|c|c|}
\hline Type of gall & Plant organ & Position & Form of gall & E. alba & E. urophylla \\
\hline GT1 & Leaf & Concealed & Globoid & $\mathrm{A}, \mathrm{B}, \mathrm{C}$ & $\mathrm{M}, \mathrm{N}, \mathrm{O}, \mathrm{P}$ \\
\hline GT2 & Leaf & Concealed & Ovoid & $\mathrm{H}, \mathrm{K}$ & $\mathrm{Q}$ \\
\hline GT3 & Twigs, stems, leaves, axillae & Concealed & Fusiform & $\mathrm{E}, \mathrm{F}$ & $\mathrm{S}, \mathrm{T}$ \\
\hline GT4 & Leaf & Concealed & Ovoid & $\mathrm{G}$ & $\mathrm{U}, \mathrm{V}$ \\
\hline GT5 & Leaf & Open & Amorphous & - & $\mathrm{W}$ \\
\hline GT6 & Leaf & Open & Ovoid & - & $X$ \\
\hline GT7 & Leaf & Open & Globoid & I & - \\
\hline GT8 & Leaf & Open & Conical & - & AA \\
\hline GT9 & Leaf & Open & Globoid & - & $\mathrm{Y}$ \\
\hline GT10 & Leaf & Open & Fusiform & $\mathrm{D}$ & - \\
\hline GT11 & Leaf & Open & Lenticular & $\mathrm{L}$ & $\mathrm{Z}$ \\
\hline GT12 & Bud & Open & Globoid & $\mathrm{J}$ & - \\
\hline GT13 & Bud & Open & Folded & - & $\mathrm{R}$ \\
\hline
\end{tabular}

Table 5. Type of gall found in the two species of eucalyptus at different elevations

\begin{tabular}{|c|c|c|c|c|c|c|c|c|c|c|c|c|c|}
\hline \multirow{2}{*}{$\begin{array}{c}\text { Elevation } \\
\text { (m asl.) }\end{array}$} & \multicolumn{13}{|c|}{ Type of gall } \\
\hline & GT 1 & GT 2 & GT 3 & GT 4 & GT 5 & GT 6 & GT 7 & GT 8 & GT 9 & GT 10 & GT 11 & GT 12 & GT 13 \\
\hline $829^{*}$ & + & + & + & + & - & - & + & - & - & + & + & + & - \\
\hline $942^{* *}$ & + & + & + & + & + & - & - & - & - & - & + & - & - \\
\hline $1621^{* *}$ & + & + & + & + & + & + & - & + & + & - & + & - & + \\
\hline $1992^{* *}$ & + & + & + & + & + & + & - & - & - & - & - & - & - \\
\hline $2457^{* *}$ & + & + & + & - & + & - & - & - & - & - & - & - & - \\
\hline
\end{tabular}

Notes: + : Found; - : No galls; * : E. alba; **: E. urophylla 
Table 6. Insects associated with galls in two species of eucalyptus, and their roles

\begin{tabular}{|c|c|c|c|c|c|c|c|c|c|c|}
\hline \multirow{2}{*}{ Order } & \multirow{2}{*}{ Family } & \multirow{2}{*}{ Morphospecies } & \multicolumn{5}{|c|}{ Elevation } & \multicolumn{3}{|c|}{ Role } \\
\hline & & & 829 & 942 & 1621 & 1992 & 2457 & Gall-inducing & Parasitoid & Inquiline \\
\hline \multirow{20}{*}{ Hymenoptera } & Bethylidae & Bethylidae sp.1 & & + & & & & & + & \\
\hline & Torymidae & Megastigmus specularis & + & + & + & & & & + & \\
\hline & & Megastigmus zebrinus & + & + & & + & + & & + & \\
\hline & & Leptocybe invasa & + & + & + & & + & + & & \\
\hline & Eulophidae & Ophelimus eucalypti & + & + & + & + & + & + & & \\
\hline & & Ophelimus maskelli & + & + & + & & + & + & & \\
\hline & & Cirrospilus sp.1 & + & & + & + & + & & + & \\
\hline & & Cirrospilus sp.2 & + & + & + & + & & & + & \\
\hline & & Eulophidae sp.1 & + & + & + & & & & + & \\
\hline & & Eulophidae sp.2 & + & + & & & & & + & \\
\hline & & Eulophidae sp. 3 & + & & & & & & + & \\
\hline & Pteromalidae & Pteromalidae sp.1 & & + & + & + & + & & + & \\
\hline & & Pteromalidae sp. 2 & & + & & + & + & & + & \\
\hline & Eupelmidae & Eupelmidae sp.1 & & + & & & & & + & \\
\hline & Encyrtidae & Encyrtidae sp.1 & + & & & & & & + & \\
\hline & Eurytomidae & Eurytomidae sp.1 & + & + & + & & & & + & \\
\hline & Braconidae & Braconidae sp.1 & & & + & + & + & & + & \\
\hline & & Braconidae sp. 2 & & & & + & & & + & \\
\hline & Scelionidae & Scelionidae sp.1 & & & + & & & & + & \\
\hline & Mymaridae & Stethyinum sp.1 & & & + & & + & & + & \\
\hline \multirow[t]{4}{*}{ Diptera } & Cecidomyiidae & Lasioptera sp.1 & + & & & & & + & & \\
\hline & & Cecidomyiidae sp.1 & + & + & & + & + & & & + \\
\hline & Fergusoninidae & Fergusonina sp.1 & + & + & + & + & + & + & & \\
\hline & Chaoboridae & Chaoboridae sp.1 & & & + & & & & & + \\
\hline Thysanoptera; Tubulifera & Phlaeothripidae & Phlaeothripidae sp.1 & + & & & & & & & + \\
\hline Lepidoptera & Tortricidae & Tortricidae sp.1 & + & & & & & & & + \\
\hline Hemiptera & Psyllidae & $\begin{array}{l}\text { Psyllidae sp.1 } \\
\text { Psyllidae sp.2 }\end{array}$ & & + & $\begin{array}{l}+ \\
+\end{array}$ & + & + & $\begin{array}{l}+ \\
+\end{array}$ & & \\
\hline
\end{tabular}


This is possible because close to the top of Mount Mutis plant diversity is decreasing (Simbolon and Sukendar 1987) and at an altitude of 2000 is covered by grasslands which affect the insect composition (Miller and Raman 2019). Heterogeneous vegetation generally has more insect diversity than homogeneous vegetation (Pimenta and Marco 2015). The galling-insect diversity value in the two types of eucalyptus and at different altitudes is classified as moderate, with index value of between one and three. Galling-insect diversity in the Mutis forest seems to be relatively high, and the condition of the ecosystem tends to be stable. However, we need more studies to understand what exactly the mechanisms of galling-insect diversity relationship to ecosystem stability. Our study showed that ecophysiological constraints have played an important role in gall diversity. The decline in gall diversity is most likely influenced by physical and biological conditions (Hortal et al. 2013; Cirimwami et al. 2019). In contrast, Carneiro et al. (2014) argue that there is a negative correlation between the species diversity of gall-forming insects and altitude, reflecting more stressful environmental conditions in the lowlands.

Based on our present results, the species diversity of galling insects and their types of gall in both E. alba and E. urophylla tend to show relative richness compared to the results of previous research (Safitri et al. 2019). Recent studies have shown that interspecific competition be an important phenomenon capable of shaping the community structure of sedentary organisms, such as gall-inducing insects (e.g., Cornelissen et al. 2013; Fagundes et al. 2018). Some characteristics of the interaction between galling insects and their host plants make this system suitable for better understanding the processes that structure natural communities. Galls are an emphatic marker of speciesspecific relationships, since about $90 \%$ of all gall-forming species are monophagous (Raman 2010), so they can be applied to understand the relationship between gall-making species richness and plant species diversity in an area (Butterill and Novotný 2015), with the potential to use galls as bioindicators (Santana and Isaias 2014). Differences in the diversity of galling insects between altitudes and between eucalyptus species are possible if there are differences in the landscape structure (Lawton 1983; Miller and Raman 2019). Increase in species richness and abundance of insects depends on the complexity of plant structure. This is confirmed by our finding that near the summit of Mount Mutis the dominance of eucalyptus decreases followed by a decrease in species richness of galling insects. However, eucalyptus trees are still more visible in the landscape and are more likely to be targeted by galling insects.

The set of colors observed in gall structures is a consequence of changes in the accumulation of plant pigments, and may change during gall development, especially from green to red (Inbar et al. 2010). Even though it is an easy trait to be registered, the color of $28.7 \%$ of the gall morphotypes was not reported in the inventories (Maia and Oliveira 2010; Santos et al. 2011b; Malves and Frieiro-Costa 2012). The plant families with the largest number of species in a given area are usually those which also host a higher richness of galls. The Myrtaceae (E. urophylla and E. alba) at Timor Tengah Selatan subdistrict were also the main hosts of galls, which confirm the pattern presented in the inventories in the areas. The green color in the galls eucalyptus indicates the presence of photosynthetic cells which can be beneficial to the host plant, because it increases the photosynthetic surface due to hyperplasia and hypertrophy of plant cells. These green balls may be a good model for the study of photosynthesis and cytological responses to painful stress. What's more, several studies in the tropics have shown that photosynthesis in galls is insufficient for maintenance of their structure, and is used as an accessory for host plant machinery, as (Oliveira et al. 2011; Castro et al. 2012). The age of the galls can affect the color variation. During senescence, chlorophyll is degraded and carotenoids and anthocyanins are no longer disguised (Dias et al. 2013). Sometimes, the color of the same gall morphotype may be same varies from dark to yellowish-green, reaching the red and even the brown colors depending on the stimuli from the galling insect and from environmental conditions such as light exposure.

In conclusion, information on the association between gall-forming insects and eucalyptus in natural and industrial forests in Indonesia is still very limited. However, the results presented in this paper indicate that Indonesian native eucalyptus has a large diversity of gallforming insects and gall-type forms associated with them, and that internal and external gall morphology varies structurally. More studies on the diversity of gall-inducing insects and gall morphology are needed to understand the adaptive significance of gall induction in eucalyptus in tropical forests in regions such as Indonesia. In addition, eucalyptus species in industrial plantations that use hybrid plants have the potential to become new adaptive zones for the diversification of species of gall insects on eucalyptus. This being one of the main factors explaining the prominent species richness of eucalyptus in industrial forests in Indonesia, many gall-forming insects are also predicted to have co-evolved. A more comprehensive study of the relationships between galling insects and Indonesian eucalyptus plants needs to be carried out, and in particular, work should be directed at comparing endemic species with limited distribution with species with wider distributions of latitude and altitude. It is hoped that this study will contribute to our understanding of the dynamics of these interactions at different spatial scales. The gall-forming insects associated with eucalyptus native to Indonesia may represent a greater species richness than those found among eucalyptus species themselves. Therefore, this information should be considered as an important component of biodiversity, which has its own specific conservation requirements in the eucalyptus forests of the mountains of eastern Indonesia and their very specific climate conditions.

\section{ACKNOWLEDGEMENTS}

We thank the Mt. Mutis foresters for their help and cooperation during this research and Nature Conservation 
Agency (BKSDA) of East Nusa Tenggara, Indonesia for the permission to work at the field sites and for logistical support. This work was supported by the BUDI-LPDP Program, for funding doctorate studies at Bogor Agricultural University, Indonesia.

\section{REFERENCES}

Barbosa M, Fernandes GW. 2014. Bottom-up effects on gall distribution In: Fernandes GW, Santos JC (eds). Neotropical Insect Galls. Springer, Dordrecht. DOI:10.1007/978-94-017-8783-3 6.

Butterill P, Novotný V. 2015. Gall-forming insects in a lowland tropical rainforest: Low species diversity in an extremely specialised guild. Ecol Entomol 40: 409-419. DOI: 10.1111/een.12198.

CABI [Commonwealth Agricultural Bureau International]. 2005. Forestry Compendium. CAB International, Wallingford, UK.

Carneiro MAA, Coelho MS, Fernandes GW. 2014. Galls in Brazilian mountains: New reports and perspectives. In: Fernandes GW, Santo JC (eds.) Neotropical Insect Galls. Springer, Dordrecht. DOI 10.1007/978-94-017-8783-3_16. [Netherlands]

Castro AC, Oliveira DC, Moreira ASFP, Lemos-Filho JP, Isaias RMS 2012. Source-sink relationship and photosynthesis in the horn-shaped gall and its host plant Copaifera lagsdorffii Desf. (Fabaceae). S Afr J Bot 83: 121-126. DOI: 10.1016/j.sajb.2012.08.007.

Cirimwami L, Doumenge C, Kahindo JM, Amani C. 2019. The effect of elevation on species richness in tropical forests depends on the considered lifeform: Results from an East African mountain forest. Trop Ecol 60: 473-484. DOI:10.1007/s42965-019-00050-Z.

Cleland EE. 2011. Biodiversity and ecosystem stability. Nature Education Knowledge 3 (10): 14

Cornelissen T, de Carvalho GCD, Viana JPR, Silva B. 2013. Interspecific competition influences the organization of a diverse sessile insect community. Acta Oecol 52: 15-18. DOI: 10.1016/j.actao.2013.07.001

De Araújo WS, Silva IPA, dos Santos BB, Gomes-klein VL. 2013. Hos plants of insect-induced galls in areas of cerrado in the state of Goiás, Brazil. Acta Bot Brasilica 27: 537-542. DOI: 10.1590/S010233062013000300011.

De Araújo WS. 2011. Can host plant richness be used as a surrogate for galling insect diversity? Trop Conserv Sci 4 (4): 420-427. DOI: 10.1177/194008291100400405.

Dias GG, Moreira GRP, Ferreira BG, Isaias RMS. 2013. Why do the galls induced by Calophya duvauae Scott on Schinus polygamus (Cav.) Cabrera (Anacardiaceae) change colors? Biochem Syst Ecol 48: 111 122. DOI: $10.1016 /$ j.bse.2012.12.013.

Espírito-Santo MM, Fernandes GW. 2007. How many species of gallinducing insects are there on earth, and where are there? Ann Entomol Soc Am 100: 95-99.

Fagundes M, Xavier RCF, Faria ML, Lopes LGO, Cuevas-Reyes P, Reis-Junior R. 2018. Plant phenological asynchrony and community structure of gall-inducing insects in a super-host tropical tree species. Ecol Evol 8 (22): 10687-10697. DOI: 10.1002/ece3.4477.

Fernandes GW, Price PW. 1992. The adaptive significance of insect gall distribution: survivorship of species in xeric and mesic habitats. Oecologia 90: 14-20. DOI: 10.1007/BF00317803.

Formiga AT, Oliveira DC, Ferreira BG, Magalhães TA, Castro AC, Fernandes GW, Isaias RMS. 2013. The role of pectic composition of cell walls in the determination of the new shape-functional design in galls of Baccharis reticularia (Asteraceae). Protoplasma 250: 899908. DOI: 10.1007/s00709-012-0473-8

Horstmann K, Floren A, Linsenmair KE. 2005. Ichneumonidae (Hymenoptera) from the canopy of tropical forests in Sabah Malaysia: A comparison between primary and secondary forests. Ecotropica 11: 41-52

Hortal J, Carrascal LM, Triantis KA, Thébault E, Meiri S, Sfenthourakis S. 2013. Species richness can decrease with altitude but not with habitat diversity. Proc Natl Acad Sci USA 110 (24): E2149-E2150. DOI: $10.1073 /$ pnas.1301663110.

Inbar M, Izhaki I, Koplovich A, Lupo I, Silanikove N, Glasser T, Gerchman Y, Perevolotsky A, Lev-Yadun S. 2010. Why do many galls have conspicuous colors? A new hypothesis. Arthropod Plant Interact 4(1):1-6. DOI: 10.1007/s11829-009-9082-7.
Isaias RMS, Carneiro RGS, Oliveira DC, Santos JC. 2013. Illustrated and annotated checklist of Brazilian gall morphotypes. Neotrop Entomol 42: 230-239. DOI: 10.1007/s13744-013-0115-7.

Koneri R. 2010. Diversity of Lucanid beetles at various altitudes in the forest of the Mount Salak Barat Unocal concession, West Java. Jurnal Matematika dan Sains 15 (2): 77-84. [Indonesian]

Ludwig JA, Reynolds JF. 1988. Statistical Ecology: A Primer Methods and Computing. JohnWiley \& Sons, New York.

Magurran AE. 2004. Measuring Biological Diversity. Blackwell Publishing, Maiden.

Maia VC, Oliveira KC. 2010. Insect galls of the Reserva Biológica Estadual da Praia do Sul (Ilha Grande, Angra dos Reis, RJ). Bio Neotrop 10 (4): 227-238. DOI:10.1590/S1676-06032010000400028.

Malves K, Frieiro-Costa FA. 2012. List of plants with galls induced by insects from the UNILAVRAS/Boqueirão Biological Reserve, Ingaí, state of Minas Gerais, Brazil. Check List 8 (3): 426-443. DOI: 10.15560/8.3.426.

Miller III DG, Raman A. 2019. Host-plant relations of gall-inducing insects. Ann Entomol Soc Am 112 (1): 1-19. DOI: 10.1093/aesa/say034.

Oliveira, DC, Isaias RMS, Moreira ASFP, Magalhães TA, Lemos-Filho JP. 2011. Is the oxidative stress caused by Aspidosperma spp. Galls capable of altering leaf photosynthesis? Plant Sci 180: 489-495. DOI: 10.1016/j.plantsci.2010.11.005.

Oliveros JC. 2007. VENNY. An interactive tool for comparing lists with Venn Diagrams. Available at: http://bioinfogp.cnb.csic.es/tools/venny/index.html.

Pimenta M, De-Marco P. 2015. Leaf beetle (Chrysomelidae: Coleoptera) assemblages in a mosaic of natural and altered areas in the Brazilian Cerrado. Neotrop Entomol 44: 242-255. DOI: 10.1007/s13744-0150280-y.

Pujiono E, Sadono R, Hartono H, Imron MA. 2019. A three decades assessment of forest cover changes in the mountainous tropical forest of Timor Island, Indonesia. Jurnal Manajemen Hutan Tropika 25 (1): 51-64. [Indonesian]

Quintero C, Garibaldi L A, Grez A, Polidori C, Nieves-Aldrey JL. 2014. Galls of the Temperate Forest of Southern South America: Argentina and Chile. In: Fernandes, Santos JC (eds). Neotropical Insect Gall. Springer, Dordrecht. DOI: 10.1007/978-94-017-8783-3_21.

Rachman E, Tihurua EF, Sunaryo S. 2012. Diversity and distribution of gall in the Bogor Botanical Gardens. Buletin Kebun Raya 15 (2): 93102. [Indonesian]

Rachman E, Tihurua, EF, Sunaryo S. 2014. Research on gall in Mount Gede Pangrango and Mount Halimun Salak National Parks, West Java, Indonesia. Berita Biologi 13 (1): 39-47. [Indonesian]

Raman A. 2010. Patterns of adaptive radiation and diversification In: Ananthakrishnan TN (eds). Insect Biodiversity: Functional Dynamics and Ecological Perspectives. Scientific Publishers, Jodhpur.

Reksosoesilo ES. 1985. Biology of the Three Important Parasites of the Pest, Orselia oryzae (Wood-Mason) (Diptera: Cecidomyiidae), as the Basis for Managing this Pest. [Dissertation]. IPB University, Bogor. [Indonesian]

Safitri B, Hidayat P, Buchori D. 2019. Resistance of some new clones of eucalyptus to insects causes gall in Mount Mutis, NTT. Jurnal Hama dan Penyakit Tumbuhan Tropika 19 (2): 109-117. DOI: 10.23960/j.hptt.219109-117. [Indonesian]

Safitri B. 2019. Insects Associated with Puru in Several Eucalyptus Clones at Mount Mutis, East Nusa Tenggara. [Thesis]. IPB University, Bogor. [Indonesian].

Santana AP, Isaias RMS. 2014. Galling insects are bioindicators of environmental quality in a conservation unit. Acta Bot Brasilica 28 (4): 594-608. DOI: 10.1590/0102-33062014abb3510.

Santos JC, Almeida-Cortez JS, Fernandes GW. 2011b. Diversity of gallinducing insects in the high altitude wetland forests in Pernambuco, Northeast Brazil. Braz J Biol 71 (1): 47-56. DOI: 10.1590/S151969842011000100008

Santos JC, de Almeida-Cortez JS, Fernandes GW. 2011a. Richness of gall-inducing insects in the tropical dry forest (caatinga) of Pernambuco. Rev Bras Entomol 55: 45-54. DOI: 10.1590/S008556262011000100009

Silva PSD, Knoechelmann CM, Tabarelli M, Almeida-Cortez JS. 2011. Richness of gall morphospecies along a secondary successional gradient of Atlantic Forest in Northeastern Brazil. R Bras Bioci 9 (3): 270-277. 
Simbolon H, Sukendar S. 1987. Vegetation and soil condition of Lelofui Mount Mutis Forest, Soe-NTT. Berita Biologi 3 (7): 6-10. [Indonesian]

Syawaluddin S, Hidayat P, Maryana N. 2019. Insects associated with Eucalyptus gall leaves in Humbang Hasundutan and Samosir Districts, North Sumatra Province. Jurnal Entomologi Indonesia 16 (1): 9-17. DOI: 10.5994/jei.16.1.9. [Indonesian]

Toma TSP, Mendonça-Júnior MS 2013. Gall-inducing insects of an Araucaria Forest in Southern Brazil. Rev Bras Entomol 57 (2): 225233. DOI: 10.1590/S0085-56262013005000001.
Ubaidillah R. 2011. Gall Insect Problem in Eucalyptus of Toba Pulp Lestari Plantation. Survey Report Toba Pulp Lestari, North Sumatra. [Indonesian]

Uechi N, Yukawa J, Tokuta M, Maryana N, Kikumura TG, Kim W. 2016. Description of the Asian chili pod gall midge, Asphondylia capsicicola sp. n., with comparative notes on Asphondylia gennadii (Diptera: Cecidomyiidae) that induces the same sort of pod gall on the same host plant species in the Mediterranean region. Appl Entomol Zool 52: 113-123. DOI:10.1007/s13355-016-0461-0.

Van Leeuwen-Reijnvaan J, Van Leeuwen WM. 1926. Zoocecidia of the Netherlands East Indies. Drukkerij de Unie, Batavia. [Ducth] 